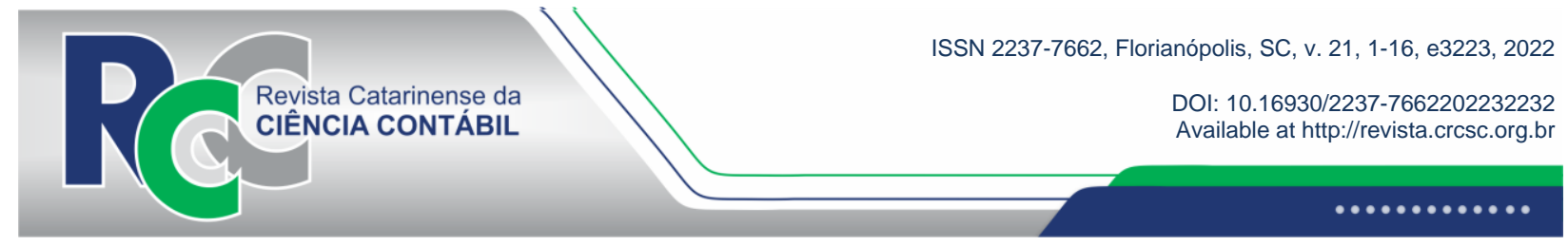

\title{
THE INFLUENCE OF CORPORATE SOCIAL RESPONSIBILITY ON THE QUALITY OF ACCOUNTING STATEMENTS OF BRAZILIAN COMPANIES
}

\author{
MARIA MACILEYA AZEVEDO FREIRE \\ Centro Universitário Estácio do Ceará \\ Address: Avenida Duque de Caxias, $101 \mid$ Centro | 60035-111 | Fortaleza/CE | Brasil. \\ (D) https://orcid.org/0000-0002-8167-0473 \\ macileya@hotmail.com
}

\author{
ANTONIO RODRIGUES ALBUQUERQUE FILHO \\ Centro Universitário Estácio do Ceará \\ Address: Avenida Duque de Caxias, $101 \mid$ Centro | 60035-111 | Fortaleza/CE | Brasil. \\ (1) https://orcid.org/0000-0003-2108-3979 \\ antoniofilhoufc@hotmail.com
}

\begin{abstract}
The interest in revealing and controlling disclosed information grows due to an increasingly demanding market that is aware of the need and effect of organizational actions. Thus, a descriptive survey was conducted with 300 companies listed on B3 in order to investigate the influence of Corporate Social Responsibility (CSR) on the quality of financial statements of Brazilian companies, treating data by applying descriptive statistics, test of difference between means, correlation, and logistic regression. We analyzed the Corporate Social Responsibility (CSR) measured by the general metric CSRHub, and the quality of information represented by the republishing of their financial statements, considering that this parameter signals low quality of the information initially disclosed. The results showed that there are statistically significant differences in the CSR concerning the companies that republish their financial statements compared to those that do not, denoting that their tends to be a higher investment in CSR in companies that do not republish their information. It was also found that the greater the CSR and the organizational size, the lower the republishing of the financial statements by the companies. Finally, it was found that the CSR negatively affects the republishing of the financial statements, presenting that the higher the CSR, the lower the probability of that the companies will republish the financial statements. Thus, companies with higher CSR levels are more likely to increase the care with the information disclosed, therefore denoting higher quality of accounting information. Thus, the hypothesis of this study that companies with higher CSR practices disclose higher quality financial statements was accepted.
\end{abstract}

Keywords: Organizational Responsibility. Quality of Accounting Information. Republishing Financial Statements.

Edited in Portuguese and English. Original version in Portuguese.

Received on 11/08/2021. Reviewed on 12/30/2021. Accepted on 01/24/2022 by Prof. Dr. Sérgio Murilo Petri (Editor-in-Chief) and Prof. Dr. Sandro Vieira Soares (Associate Editor). Published on 02/7/2022.

Copyright @ 2022 RCCC. All rights reserved. Quoting parts of articles without prior authorization is allowed, as long as the source is identified. 


\section{INTRODUCTION}

Given a greater awareness of the needs and expectations generated in a company, the organizational interest in associated factors and greater demands of the capital market regarding the care and control in the disclosure of information grows (Silva, Noriller, Silva, \& Niyama, 2018). Organizations have been searching for new strategies and mechanisms that represent greater security for investors and the place in which they are inserted, and that reflect not only in the entity's performance, but the positive impacts of the company in its social environment (Berens, Van Riel, \& Van Rekom, 2007; Koprowski, Krein, Barichello, Mazzioni, \& Dal Magro, 2019).

In this perspective, Corporate Social Responsibility (CSR) presents itself as an instrument of great organizational value, this is due to the fact that it corresponds to a broader responsibility of the organization to its various stakeholders (Rao \& Tilt, 2016). Thus, it includes practices that direct greater care, linked to environmental protection, relations with local communities, working conditions, donations, corporate governance (Berens et al., 2007), as well as more transparent and safer financial information disclosure for all stakeholders, compared to organizations that do not meet the same social criteria (Kim, Park, \& Wier, 2012).

Meanwhile, the quality of information is essential (Silva, Takamatsu, \& Avelino, 2017), since CSR works directly with information about its actions, thus, the company must usually provide accounting statements that offer more dependable, understandable, comparable, and relevant information about what was done (Degenhart, Mazzuco, \& Klann, 2017). Accounting information needs to be of quality, making actual information about the company's reality available to users (Healy \& Wahlen, 1999). According to Ball (2006), different situations and practices can influence the quality of information, enabling a more assiduous accountability and balance as to what is disclosed, thus reflecting on the financial statements made public.

The debates about the quality of financial statements have been growing in the literature, being addressed in the national and international markets. In this context, they are generally associated with the management of results, relevance, and timeliness of information (Moura, Theiss, \& Cunha, 2014; Herculano \& Moura, 2015), treating the use of information as something that can greatly impact the company. They are also presented focused on corporate conduct (Bandeira, Góis, De Luca, \& Vasconcelos, 2015), where the poor quality of the statements shown is reflected in the investor's decision making. Another factor that may interfere with the quality is the existence of an inconsistency among the disclosed information, forcing the company to republish their statements to disclose the corrected baseline (Habib \& Jiang, 2015), thus shining a negative light on the data disclosed in a previous period.

Republishing financial statements consists in the restatement of statements previously published with errors, whether qualitative or quantitative, as well as organizational frauds regarding the financial statements already disclosed (Benyoussef \& Khan, 2017; Chiudini, Cunha, \& Marques, 2018; He \& Chiang, 2013). This instrument, presents itself as an indication of the poor quality of disclosed information (Akhigbe, Kudla, \& Madura, 2005), and may impact investor decision-making (Soares, Motoki, \& Monte-Mor, 2018), and signal distinct situations to the market, such as manipulating statements (Dechow, Ge, \& Schrand, 2010; Marques, Amaral, Souza, Santos, \& Belo, 2017).]

From the standpoint of the Signaling Theory, Spence (1973) states that organizations seek to send signals that are decisive in reducing information asymmetry, allowing users to make their choices with greater clarity given the various offers. CSR is a way to signal organizational practices and concerns to the market that positively impact the investor's view (Freitas, Santos, \& 
Crisóstomo, 2019), thus, it can also signal greater control and quality of the statements revealed (Kim et al., 2012).

Given the relevance of the subject, the following question arose: What is the influence of Corporate Social Responsibility on the quality of financial statements? In order to answer the study's question, the research objective was defined as the investigation of CSR's influence on the quality of financial statements of Brazilian companies. Therefore, the study considered a sample of 300 companies and the interval from 2015 to 2019.

The quality of financial statements is a fundamental factor for decision making (Rezende, 2010; Silva et al., 2017), (Rezende, 2010; Silva et al., 2017), since, when considering the relevance of information in the decision-making power, any inconsistency in the statements can greatly impact the organization's future (Li, Park, \& Wynn, 2018). In this context, CSR is a tool that aims to bring benefits regarding the actions adopted, but also regarding the reliability and transparency of the information disclosed (Freitas et al., 2019; Kim et al., 2012).

Thus, this study is justified considering the importance of these organizational parameters for stakeholders, since they can be determinants as influencers of decision-making power (Degenhart et al., 2017), denoting greater clarity for the stakeholder as to the influence of companies that tend to invest more in CSR and the relevance of accounting information (Hedlund, 2021). Meanwhile, it presents the poor quality of information measured by the republishing of financial statements associated with the disclosure of socially responsible companies, considering it as a low quality measure due to the fact that companies that republish their statements tend not to present the information clearly and timely, making it difficult for stakeholders' to analyze, indicating failures in the disclosure of the entity's economic and financial information (Flanagan, Muse, \& O'Shaughnessy, 2008). (Flanagan, Muse, \& O’Shaughnessy, 2008).

The relevance of the theme to further advances and directed discussions is also justified, as it is indicated denoted as something seldom exposed in the literature when dealing with the quality of information, mainly measured by the republishing of financial statements (Soares et al., 2018). In this sense, it is believed that this study will contribute to broaden the view of the relationship between CSR and the quality of information, considering the impact and consequences of these elements in Brazilian companies. Thus, the study may reveal relevant contributions for investors, regulators and various stakeholders, as an instrument effectively provides knowledge of the development and positive factors in these entities, jointly vesting great relevance for further clarification and expansion of the discussion of the subjects in the economic and academic spheres, and may help regulators understand the business practices of entities and behavior of accounting reports republished in the light of CSR, with more clarity.

\section{THEORETICAL BACKGROUNDS}

This section presents the theoretical and empirical positions that underlie the development of the research rationale. This section also highlights the development of the hypothesis during the arguments about the study's constructs.

\subsection{Corporate social responsibility in the quality of financial statements of Brazilian companies}

CSR has been taking great proportions among organizational practices, since entities are increasingly concerned about the impact they can cause to the environment in which they operate, acting to minimize damage (Mcwilliams \& Siegel, 2001), and provide greater transparency (Kim et al., 2012; Baraibar-diez \& Sotorrío, 2018). In this way, it not only brings benefits for the social environment, but obtains positive effects in the opinion of stakeholders in the face of such actions(Rao \& Tilt, 2016). According to Servaes and Tamayo (2013), CSR corresponds to the organization's commitment to provide greater care for sustainable economic development, thus 
contributing to superior advances in the quality of life of employees, families, community, and society.

In the academic sphere, CSR has been addressed and measured in different ways, among them the Corporate Sustainability Index (ISE) (Nossa et al., 2009), considered a tool for analyzing the performance of companies listed on B3 related to the aspect of corporate sustainability, based on economic efficiency, environmental balance, social justice, and corporate governance (BM\&FBovespa, 2017). As well as, often associated with the Social Balance of the IBASE Model (2017), in which internal, external, and environmental social benefits are presented (Degenhart et al., 2017), and CSRHub that presents 12 CSR indicators grouped into four categories, namely: employees, environment, community and governance (Prudêncio, Forte, De Luca, \& Vasconcelos, 2019).

According to Scholtens and Kang (2013), entities that are more concerned about their social actions and CSR practices are more likely to signal that they are "good companies," in addition to bringing a positive reflection to their attitudes in the capital market (Blacconiere \& Patten, 1994), also strengthening their image to stakeholders (Servaes \& Tamayo, 2013). In this context, the presentation of such characteristics may reflect in the way the organization presents its data, denoting greater care in the preparation and disclosure of the company's economic and financial information.

Information is seen as an indispensable element for decision-making power, providing greater foundation for secure opinions and to reflect on the company's own actions (Rezende, 2010). Thus, the accounting reports are seen as definitive representatives of the entity, revealing its equity and financial situation, and acting as indispensable sources regarding its positioning and progress (Moura et al., 2017).

In this perspective, the quality of the information is something of great value, requiring greater care and clarity as to what is disclosed, mainly because it is an essential element for investor decision making. (Chiudini et al., 2018). Moreover, the quality financial statements can bring numerous benefits, not only in terms of more coherent and concise decisions (Sousa, Fernandes, Bezerra, \& Ribeiro, 2016), but also for the company's image in the market where it operates (Bandeira et al., 2015). Lee and Masulis (2009) explain poor quality generates reflects on the company's external investors, is linked to uncertainties about the organization's real financial status and can induce a decrease in demand for new equity, generating higher costs and risk.

The national literature exposes the poor quality of financial statements measured mainly by performance management (Moura et al., 2014; Herculano \& Moura, 2015), or corporate misconduct (Bandeira et al., 2015) linked to the entity's reputation.. However, the poor quality of financial reports can be associated with other factors, such as the republication of financial statements (Li et al., 2018), since it indicates the material inaccuracy of the disclosed information, presenting data that do not represent the company's actual status, making it necessary to later disclose the corrected elements (Cianci, Clor-proell, \& Kaplan, 2019). The republication of financial statements can occur voluntarily, where there is no requirement from the regulatory body, or compulsorily, where the CVM (Brazilian securities and exchange commission) requires that the information be corrected and restated (Marques et al., 2017). Thus, the way the entity is managed can say a lot about the quality of the information disclosed and can send signals to stakeholders indicating greater control by the company, or not, over the financial statements presented.

When considering factors associated as CSR, few studies have examined the relationship of CSR and the quality of the information disclosed. Among the studies present in the literature, Degenhart et al. (2017) analyzed the relationship between CSR and the relevance of accounting information of Brazilian companies in the period from 2011 to 2015. The authors found that CSR has a positive relation with the relevance of accounting information. Kim et al. (2012) examined whether socially responsible American companies behave differently from others in their financial 
reporting regarding the quality shown. They concluded that socially responsible companies are less likely to manage earnings, manipulate activities, and be the subject of SEC investigations.

In this period, the issuance of evidence of organizational improvements, such as those of companies that operate with CSR practices, can signal confirmatory aspects to the market regarding the quality of financial statements disclosed (Costa, Correia, Paulo, \& Lucena, 2018), making it possible to associate greater practices of social and environmental actions as a factor that reflects control, timeliness and reliability of what is presented to stakeholders, thus indicating higher levels of quality in the disclosure of their financial statements (Degenhart et al., 2017), therefore not needing to republish them. Thus, the hypothesis of the study is developed:

General hypothesis: Companies that present Corporate Social Responsibility practices disclose higher quality financial statements.

\section{METHODOLOGY}

\subsection{Population and sample}

The population consists of all active companies listed on B3 S.A. that were present in the Economatica ${ }^{\circledR}$ database on $02 / 15 / 2020$. The sample was formed considering the companies with available data for the construction of variables, comprising the interval 2015, 2016, 2017, 2018 and 2019, corresponding to a time of relevant comparison among the organizations and for the use of panel data (Wooldridge, 2007). The result was a sample of 300 companies.

Table 1 presents the list of organizational segments based on the sample and considering the number of associated entities.

Table 1

List of company segments

\begin{tabular}{c|c}
\hline Organizational segment & Number of companies \\
\hline Industrial goods & 51 \\
\hline Communications & 5 \\
\hline Cyclical consumption & 72 \\
\hline Non-cyclical consumption & 21 \\
\hline Finances & 50 \\
\hline Basic materials & 28 \\
\hline Oil, gas, and biofuels & 10 \\
\hline Health & 17 \\
\hline Information technology & 6 \\
\hline Public utility & 40 \\
\hline Total of companies & $\mathbf{3 0 0}$
\end{tabular}

Source: Prepared by the authors.

From Table 1 it can be deduced that 71 companies in the sample comprise the Cyclical Consumption sector, followed by the Industrial goods (51 companies) and Financial (50 companies) sectors, while Communications (5 companies), Information Technology (6 companies) and Oil, Gas and Biofuels (10 companies) were the sectors with the fewest companies in the sample.

\subsection{Research Variables and Data Collection}

Data collection relied on CVM website for information about the companies' financial statements republishing, the CSRHub Database for CSR practices, and Economatica for financial information. 
Table 2 shows the description, sources and theoretical support for the variables used in the research.

Table 2

Variables used in the research

\begin{tabular}{|c|c|c|c|c|}
\hline Variable & Proxy & Description & Data source & $\begin{array}{c}\text { Theoretical } \\
\text { support }\end{array}$ \\
\hline \multicolumn{5}{|c|}{ Dependent variable } \\
\hline $\begin{array}{l}\text { Low quality of } \\
\text { accounting statements }\end{array}$ & $\begin{array}{l}\text { Republishing } \\
\text { (REPUB) }\end{array}$ & $\begin{array}{l}\text { Dummy variable that } \\
\text { assumes value } 1 \\
\text { when the statement is } \\
\text { republished and value } \\
0 \text { (zero) otherwise }\end{array}$ & CVM website & $\begin{array}{c}\text { Chiudini et al. } \\
\text { (2018); Zhang, } \\
\text { Huang and } \\
\text { Habid (2018). }\end{array}$ \\
\hline \multicolumn{5}{|c|}{ Independent variable } \\
\hline $\begin{array}{l}\text { Corporate Social } \\
\text { Responsibility }\end{array}$ & CSR & $\begin{array}{l}\text { General Metric } \\
\text { CSRHub }\end{array}$ & CSRHub database & $\begin{array}{c}\text { Yasser, Al } \\
\text { Mamun, } \\
\text { Ahmed (2017). }\end{array}$ \\
\hline \multicolumn{5}{|c|}{ Control variables } \\
\hline Company size & SIZE & $\begin{array}{l}\text { Natural log of total } \\
\text { assets }\end{array}$ & Economatica & $\begin{array}{c}\text { Cao, Du e } \\
\text { Hansen (2017); } \\
\text { Zhang et al. } \\
\text { (2018). }\end{array}$ \\
\hline Indebtedness & IND & $\begin{array}{l}\text { Ratio between Total } \\
\text { Liabilities and Total } \\
\text { Assets }\end{array}$ & Economatica $^{\circledR}$ & Tavares (2016). \\
\hline Performance & ROA & $\begin{array}{l}\text { Ratio between Net } \\
\text { income and Total } \\
\text { assets }\end{array}$ & Economatica $^{\circledR}$ & $\begin{array}{l}\text { Shahzad et al. } \\
\text { (2020). }\end{array}$ \\
\hline Leverage & GAF & Net Profit/Ebitda & Economatica $^{\circledR}$ & $\begin{array}{l}\text { Muñoz et al. } \\
(2020) .\end{array}$ \\
\hline YEAR & YEAR Dummies & $\begin{array}{c}\text { Assume } 1 \text { for the } \\
\text { year and } 0 \text { for the } \\
\text { others. }\end{array}$ & Economatica $^{\circledR}$ & $\begin{array}{c}\text { Ximenes, e } \\
\text { Ferreira (2021). }\end{array}$ \\
\hline
\end{tabular}

Source: Prepared by the authors based on the literature.

The study's dependent variable corresponds to the Low quality of the Financial Statements, measured through the republishing of the statements, analyzed by a dummy variable that assumes the value " 1 " when there statements are republished and the value "0" (zero) otherwise (Zhang et al., 2018), this way all types of republishing were considered (compulsory and voluntary). As an independent variable we have the CSR, which considered the general evaluation metric CSRHub (Yasser, Al mamun \& Ahmed, 2017).

The CSRHub database provides data on its dimensions based on fourteen indicators grouped into four categories: employees (compensation, diversity and labor rights, training, health and safety indicators), environment (energy and climate change, environmental policy and reports, resource management indicators), community (community development and philanthropy, products, human rights and supply chain indicators) and governance (board, leadership ethics, transparency and reporting indicators), thus covering social, environmental and economic aspects (Ribeiro et al., 2017). The average of the four categories described forms the overall CSR metric, providing standardization and a score ranging from 0-100.

The control variables are represented by company size, characterized by the natural log of total assets (Cao et al., 2017), indebtedness, measured by the ratio of total liabilities to total assets (Tavares, 2016), performance measured by the ratio of net income to total assets (Shahzad et al., 
2020); Leverage, obtained through the ratio of net income to Ebitda (Muñoz et al., 2020); and YEAR Dummies.

\subsection{Data Analysis Procedures}

In order to meet the objective of the study and test the formulated hypothesis, a descriptive analysis was initially performed for a better understanding of the variables, considering the continuous variables of the study. The difference test between CSR and financial statement republishing averages was also performed, for which two groups were considered: G1 of companies that did not republish and G2 of companies that republished their financial information. Additionally, Pearson's correlation test was carried out between the variables and the republication of the financial statements. Finally, a logistic regression analysis with panel data was performed to conjecture about the influence of CSR on the quality of the financial statements disclosed.

The data organization takes place in time series based on the panel data that show the variables' evolution not only in a given instant of time, but over time and in view of the observations made (Fávero et al., 2009).

The panel data analysis used the pooled independent cross-sections (POLS - pooled ordinary least squares), fixed effects and random effects (random effects) approaches. In the case of the pooled model, no elements linked to behavioral differences of the entities within the set of observed data are found; however, the fixed effects approach takes considers the existence of significant differences in the behavior of the companies. The random effects model analyzes the differences of each individual as random, in which similarities are verified with the observations of the sample (Fávero et al., 2009).

Thus, the Equation below presents the econometric model of the study.

$$
R E P U B i j=\beta 0+\beta 1 R S C i j+\beta 2 T A M i j+\beta 3 E N D i j+\beta 4 R O A i j+\beta 5 G A F i j+\varepsilon_{i j}
$$

Furthermore, it should be noted that the Chow test was also performed to identify the model (Pool or fixed effects). Then, the Breusch-Pagan Lagrange multiplier test (for pool and random effects) and, finally, the Hausman test, were also used to identify the most representative (fixed or random) (Fávero et al., 2009).

Moreover, a descriptive statistic of the variables of interest of the study was performed prior to the regression analysis, from which measures of central tendency and variability were extracted, in order to preview the data behaviors. Likewise, the test of difference between means (Student's t-test) was conducted to compare companies that do not republish and those that republish their financial statements, but Pearson's correlation was also used to verify the association between the study variables, given that the data met the assumption of normality.

\section{PRESENTATION AND ANALYSIS OF RESULTS}

\subsection{Descriptive statistics}

Below we present the characteristics of the sample of companies in order to understand the research data distribution. First is an overview of the variables of the study is presented, symbolizing their overall distribution, then is the verification of differences, relationship and influence among the variables.

Table presents the description of the continuous and discrete variables used in the research. 
Table 3

Characterization of continuous and discrete variables

\begin{tabular}{c|c|c|c|c}
\hline Variables & Minimum & Maximum & Mean & Standard deviation \\
\hline CSR & 34.0 & 67.0 & 53.87 & 6.097 \\
SIZE & 2.0365 & 21.276 & 14.61 & 2.526 \\
IND & 0 & 46.75 & 0.922 & 2.647 \\
ROA & -13.30 & 2.217 & 0.174 & 3.653 \\
GAF & -140.974 & 282.839 & 1.004 & 11.71 \\
\hline
\end{tabular}

Source: Research data.

By Table 3 it is observed that among the companies that implement CSR actions signaled an average value of 53.87, and there are companies that presented a minimum of 34 and a maximum of 67, with the value being significantly heterogeneous among the companies (Standard Deviation $=6.097)$. The other variables (SIZE, IND, ROA, GAF) were dispersed, showing heterogeneous values among the companies.

Consequently, several studies highlight that Brazilian companies have been signaling the republishing of their statements (Tavares, 2016; Chiudini et al., 2018; Soares et al., 2018).

In the Brazilian scenario, although most republishing is voluntary, which may at first signal greater transparency to the market, Palmrose, Richardson and Scholz (2004), Cao, Myers and Omer (2012) and Marque et al. (2017) point out that this may present relevant adverse effects on the company's capital cost and reputation. Thus, the quality of disclosed information can be affected by numerous contextual factors, including CSR (Degenhart et al., 2017).

Regarding the CSR, it is verified that Brazilian companies are increasingly socially responsible, considering there is greater attention from society in relation to their conduct, showing that there is a concern beyond economic gains. Thus, as pondered by Albuquerque Filho et al. (2019) page 13 apud Beltratti (2005) "socially responsible companies are often also the most respected and profitable companies."

\subsection{Test of Means}

Table 4 shows the test of means of the CSR between companies that do not republish and that do republish their financial statements, signaling the similarities and differences between the CSR and republishing variables.

Table 4

CSR test of means between companies that republish and do not republish their financial statements

\begin{tabular}{c|c|c|c|c|c|c}
\hline \multirow{2}{*}{ Variable } & \multirow{2}{*}{ REPUB } & \multirow{2}{*}{$\mathbf{N}$} & \multicolumn{2}{|c|}{ Student's t test } & \multicolumn{2}{|c}{ Levene's test } \\
\cline { 4 - 7 } & & & Mean & Sig. & F & Sig. \\
\hline \multirow{2}{*}{ CSR } & G1 & 170 & 54.010 & 0.407 & 0.001 & 0.981 \\
\hline
\end{tabular}

Source: Prepared by the authors.

*significant at $1 \%$.

Key: G1 - companies that did not republish and G2 - companies that did republish.

Table 4 shows statistically significant differences in the CSR of companies that republish their financial statements compared to companies that do not republish their financial statements. The CSR of companies that do not republish (G1) is higher than that of companies that republish (G2), indicating that companies that do not republish their financial statements tend to present higher CSR. 
In this context, CSR is an instrument that helps increase benefits regarding the actions adopted, but also regarding the reliability and transparency of the information disclosed (Freitas et al., 2019; Kim et al., 2012), in this case, the non-republishing of accounting information. Whereas, according to Helou Neto and Pereira (2010), republications in the Brazilian scenario show a negative reaction from the market when it is a CVM-mandated republishing.

\subsection{Pearson's Correlation}

Table 5 demonstrates the Pearson's correlation between the variables and REPUB.

Table 5

\section{Correlation of variables}

\begin{tabular}{c|c|c}
\hline \multirow{2}{*}{ Variables } & Expected & Observed Result \\
\cline { 3 - 3 } & Result & $\boldsymbol{R E P U B}$ \\
\hline CSR & - & $-0.39(* *)$ \\
SIZE & - & $-0.08(* *)$ \\
IND & + & $+0.11(\mathrm{NS})$ \\
ROA & - & $+0.02(\mathrm{NS})$ \\
GAF & - & $+0.03(\mathrm{NS})$ \\
\hline
\end{tabular}

Source: Prepared by the authors.

** significant at 5\%; NS: Not significant.

Table 5 reveals that there is an inverse correlation between CSR and the Republishing of Financial Statements (REPUB). Furthermore, it is noted that company size also showed a negative association with REPUB. The IND, ROA and AF variables did not show statistical significance. Thus, it is highlighted that the higher the CSR and size, the lower the republishing of financial statements by companies.

Such results corroborate what Bischoff, Finley e Leblanc (2008) state, that the stock market sees republishing as something negative, and indicative of fraud or the absence of quality statements. Thus, taking information quality into consideration, the negative relationship between CSR and REPUB is in line with the findings of Schuster and Klann (2019) and Malo-Alain, Melegy, and Ghoneim (2019), who also analyzed the effects of CSR on accounting information quality.

Therefore, it is inferred that to the extent that companies expose their CSR actions as a form of transparency, they also tend to stimulate the quality of their information by not republishing their statements.

\subsection{Logistic regression}

Table 6 shows the influence of CSR on REPUB. 
Table 6

Logistic regression of CSR influence on REPUB

\begin{tabular}{|c|c|c|c|}
\hline \multirow{2}{*}{ Variable } & \multicolumn{3}{|c|}{ Republication of financial statements } \\
\hline & Model I & & \\
\hline \multicolumn{2}{|c|}{ Random effects } & Tolerance & VIF \\
\hline CSR & $-0.016 * *$ & 0.976 & 1.025 \\
\hline SIZE & $-0.083 * * *$ & 0.907 & 1.103 \\
\hline IND & 0.062 & 0.833 & 1.200 \\
\hline ROA & 0.032 & 0.899 & 1.112 \\
\hline GAF & -0.005 & 0.991 & 1.009 \\
\hline Constant & 2.627 & - & - \\
\hline Dummy_YEAR & Yes & - & - \\
\hline Wald Chi2 & \multirow{4}{*}{\multicolumn{3}{|c|}{$\begin{array}{c}5.176 \\
0.000^{*} \\
0.150 \\
1.089\end{array}$}} \\
\hline p-value & & & \\
\hline $\mathrm{R}^{2}$ & & & \\
\hline Average VIF & & & \\
\hline
\end{tabular}

Source: Prepared by the authors.

$(*),(* *),(* * *)$ significant at $1 \%, 5 \%$ and $10 \%$, respectively.

In Table 6 it is observed that the Wald Chi2 was significant at $1 \%$, enabling the model analysis. The explanatory power of the model $\left(\mathrm{R}^{2}\right)$ corresponds to $15 \%$ and the VIF indicates the non-multicollinearity between the independent variables $(\mathrm{VIF}<5)$.

The regression allows us to verify that the CSR presented statistical significance at $5 \%$. The negative coefficient (CSR $=-0.016)$ shows a negative influence of CSR on REPUB. Thus, it is deduced that the higher the CSR, the lower the probability of Financial Statements being Republished (REPUB) by companies, with subsequent impacts on the quality of their accounting information. Thus, the hypothesis of this study, that companies with Corporate Social Responsibility practices disclose higher quality financial statements, is accepted.

In the meantime, it can be seen that issuing evidence of organizational improvements can signal proof of quality financial statements to the market (Costa et al., 2018), presenting CSR as a positive tool regarding accounting information (Degenhart et al., 2017), corroborating the studies of Kim et al. (2012) and Scholtens and Kang (2013) that entities that are more concerned about their social actions and CSR practices, are more likely to signal that they are "good companies," which reflects on the information disclosed by them.

Furthermore, as pondered by Kim et al. (2012), to the extent that CSR is a matter of rising interest, given that investors, clients, and stakeholders demand greater transparency, companies need to disclose their information to the market, being able to insert in this context their environmental, social and economic actions, just as corroborated by the Signaling Theory.

In this scenario, the negative relationship between CSR and REPUB corroborates what was demonstrated by Albuquerque Filho et al. (2019), who pointed out that CSR induces greater transparency, and can contribute to the improvement of the company's brand and reputation by alleviating its concerns about negative inquiries, such as republishing its financial statements.

Furthermore, it was also found that company size was negative and statistically significant $(\mathrm{SIZE}=-0.083$, p-value $<1 \%)$, showing that there is a lower possibility of republishing among larger companies, which means they consequently tend to present better quality information. On the other hand, the other variables (IND, ROA, and AF) did not show statistical significance.

It should be emphasized that, although a positive relationship of size in republication (Khalil \& Ozkan, 2016; Marques et al., 2017) has been verified in previous studies, in the Brazilian context, most republishing is spontaneous (voluntarily) (Marques et al., 2017). This means, according to Marques (2016), that the materials republished are not necessarily a reflection of some kind of irregularity. The study by Helou Neto and Pereira (2010), for example, revealed that, 
in the Brazilian scenario, only mandatory republications generate a negative effect on the information disclosed by companies.

\section{FINAL CONCLUSIONS}

With the purpose of investigating the influence of CSR on the quality of the financial statements of Brazilian companies, a literature review was carried out based on the subject, similar studies and data analysis performed through statistical treatment. In this context, the variable Republishing of Financial Statements was considered as a factor of low information quality, and the general metric CSRHub as a CSR measure.

The results of the study showed that there are statistically significant differences in the CSR of companies that republish their financial statements compared to companies that do not republish their statements, indicating that companies that do not republish their statements tend to have a higher CSR, implying a greater concern by companies that have higher investments in CSR with the disclosure of quality information.

This statement can be verified along the other statistical analyses conducted, such as in the correlation analysis, which showed a negative correlation between CSR and the republishing of financial statements, thus pointing out that the higher the CSR and the organizational size, the lower the republishing of financial statements by companies.

A negative influence of the CSR on the republishing of the financial statements was also found when performing the regression analysis in an attempt to verify the influence between the variables, verifying that the higher the CSR, the lower the probability of the companies republishing the financial statements.

During this time, companies with higher levels of CSR show greater care with the information disclosed, therefore, there is a greater possibility of not republishing their financial information, implying higher quality of the information reported. Thus, we accept the hypothesis of this study that companies with CSR (practices focused on employees, environment, community, and governance, thus covering social, environmental, and economic aspects) disclose higher quality financial statements.

Based on the analysis of the influence of CSR on the quality of Brazilian company financial statements, from the perspective of the republishing of financial statements, it was possible to understand the relationship between CSR and quality of information, allowing the submission of information on organizational aspects that enable the shareholder to make the best decision, who, in general, looks for entities that demonstrate greater reliability and responsibility.

Therefore, this study contributes to the literature by identifying this gap, since advances in knowledge, debates based on previous studies and results found are pointed out, especially from the standpoint of the Signaling Theory in Brazilian organizations, presenting greater evidence of the relevance of companies investing in CSR and subsequently disclosing this in reports, allowing an influence over the quality of the evidenced released, in addition to providing benefits in the face of social and environmental actions, revealing a company with a more ethical posture. It is also emphasized that the results explained here, as well as the considerations presented, can be used to subsidize an analysis of organizations with specific characteristics and markets, thus, being limited to Brazilian companies listed on B3, not making it possible to obtain information related to other markets.

For future studies, the use of distinct measures CSR or information quality to study these precepts in other markets is suggested; and to analyze CSR as a moderator in relations such as competitiveness and associated effects, thus allowing a more accurate view of striking factors and that can impact the future of the organization. 


\section{REFERENCES}

Akhigbe, A., Kudla, R. J., \& Madura, J. (2005). Why are some corporate earnings restatements more damaging? Applied financial economics, 15(5), 327-336.

Albuquerque Filho, A. R., Sousa, A. L. C., Silveira Lopes, H. S., Guimarães, D. B., \& Ponte, V. M. R. (2019). Influência da Internacionalização e da Governança Corporativa na Responsabilidade Social Corporativa. Iberoamerican Journal of Strategic Management, 18(3), 397-419.

Ball, R. (2006). International Financial Reporting Standards (IFRS): pros and cons for investors. Accounting and business research, 36(sup1), 5-27.

Bandeira, M. T. D. S. S., Góis, A. D., Luca, M. M. M., \& Vasconcelos, A. C. (2015). Reputação corporativa negativa e o desempenho empresarial. Revista de Contabilidade e Organizações, 9(24), 71-83.

Baraibar-Diez, E., \& Sotorrío, L. L. (2018). O efeito mediador da transparência na relação entre responsabilidade social corporativa e reputação corporativa. Revista Brasileira de Gestão de Negócios, 20, 05-21.

BenYoussef, N., \& Khan, S. (2017). Identifying fraud using restatement information. Journal of Financial Crime, 24(4), 620-627.

Berens, G., Van Riel, C. B., \& Van Rekom, J. (2007). The CSR-quality trade-off: when can corporate social responsibility and corporate ability compensate each other? Journal of Business Ethics, 74(3), 233-252.

Bischoff, J., Finley, J., \& LeBlanc, D. (2008). Financial statement restatements: Causes and effects. Tennessee CPA Journal, 5-7.

Blacconiere, W. G., \& Patten, D. M. (1994). Environmental disclosures, regulatory costs, and changes in firm value. Journal of accounting and economics, 18(3), 357-377.

Cao, L., Du, Y., \& Hansen, J. Ø. (2017). Foreign institutional investors and dividend policy: Evidence from China. International Business Review, 26(5), 816-827.

Cao, Y., Myers, L. A., \& Omer, T. C. (2012). Does company reputation matter for financial reporting quality? Evidence from restatements. Contemporary Accounting Research, 29(3), 956-990.

Chiudini, V., Cunha, P. R., \& Marques, L. (2018). Relação entre a republicação das demonstrações contábeis e o Audit Delay. Revista Catarinense da Ciência Contábil, 17(51), 89-107.

Cianci, A. M., Clor-Proell, S. M., \& Kaplan, S. E. (2019). How do investors respond to restatements? Repairing trust through managerial reputation and the announcement of corrective actions. Journal of Business Ethics, 158(2), 297-312. 
Costa, I. L. D. S., Correia, T. D. S., Paulo, E., \& Lucena, W. G. L. (2018). Impacto do disclosure voluntário: valor da empresa e informações socioambientais nas companhias abertas. Revista Contabilidade, Gestão e Governança-CGG, 21(2), 271-287.

Dechow, P., Ge, W., \& Schrand, C. (2010). Understanding earnings quality: A review of the proxies, their determinants and their consequences. Journal of accounting and economics, 50(23), 344-401.

Degenhart, L., Mazzuco, M. S. A., \& Klann, R. C. (2017). Relevância das informações contábeis e a responsabilidade social corporativa de empresas brasileiras. Base Revista de Administração e Contabilidade da UNISINOS, 14(3), 157-168.

Fávero, L. P., Belfiore, P., Silva, F. D., \& Chan, B. L. (2009). Análise de dados: modelagem multivariada para tomada de decisões. Rio de Janeiro: Elsevier.

Flanagan, D. J., Muse, L. A., \& O'Shaughnessy, K. C. (2008). An overview of accounting restatement activity in the United States. International Journal of Commerce and Management, 18(4), 363-381.

Freitas, M. R. O., Santos, S. M., \& Crisóstomo, V. L. (2019). Nível de abrangência da informação ambiental divulgada nos relatórios de sustentabilidade de empresas brasileiras com potencial de impacto ao meio ambiente. Revista Contabilidade e Controladoria, 10(3), 143-161.

Habib, A., \& Jiang, H. (2015). Corporate governance and financial reporting quality in China: A survey of recent evidence. Journal of International Accounting, Auditing and Taxation, 24, 2945.

He, L. J., \& Chiang, H. T. (2013). Market reaction to financial statement restatement: A study on the information and insurance role of auditors. Advances in Management and Applied Economics, 3(4), 37.

Healy, P. M., \& Wahlen, J. M. (1999). A review of the earnings management literature and its implications for standard setting. Accounting horizons, 13(4), 365-383.

Hedlund, P. R. (2021). Influência da responsabilidade social corporativa na qualidade das informações contábeis reportadas ao usuário. Dissertação de Mestrado, Universidade Regional do Noroeste do Estado do Rio Grande do Sul.

Helou Neto, F. H., \& Pereira, C. C. (2010). Impacto da republicação de demonstrações financeiras no preço das ações de empresas brasileiras. Revista Contemporânea de Contabilidade, 7(14), 29-50.

Herculano, H. D. A., \& Moura, G. D. (2015). Informação contábil e concentração acionária: Análise sob a ótica da persistência e da oportunidade. Revista Ambiente Contábil, 7(2), 231247.

Khalil, M., \& Ozkan, A. (2016). Board independence, audit quality and earnings management: Evidence from Egypt. Journal of Emerging Market Finance, 15(1), 84-118. 
Kim, Y., Park, M. S., \& Wier, B. (2012). Is earnings quality associated with corporate social responsibility? The accounting review, 87(3), 761-796.

Koprowski, S., Krein, V., Barichello, R., Mazzioni, S., \& Dal Magro, C. B. (2019). Influência das conexões políticas e da evidenciação socioambiental no custo de capital. Contextus-Revista Contemporânea de Economia e Gestão, 17(2), 98-128.

Lee, G., \& Masulis, R. W. (2009). Seasoned equity offerings: Quality of accounting information and expected flotation costs. Journal of Financial Economics, 92(3), 443-469.

Li, Y., Park, Y. I., \& Wynn, J. (2018). Investor reactions to restatements conditional on disclosure of internal control weaknesses. Journal of Applied Accounting Research, 19(3), 423-439.

Malo-Alain, A. M., Melegy, M. M. A. H., \& Ghoneim, M. R. Y. (2019). The effects of sustainability disclosure on the quality of financial reports in Saudi business environment. Academy of Accounting and Financial Studies Journal, 23(5), 1-12.

Marques, V. A., Amaral, H. F., Souza, A. A., Santos, K. L., \& Belo, P. H. R. (2017). Determinantes das republicações no mercado brasileiro: Uma análise a partir dos incentivos ao gerenciamento de resultados. Revista de Educação e Pesquisa em Contabilidade (REPeC), 11(2), 191-213.

Marques, V. (2016). Qualidade das Informações Financeiras e o Ambiente Regulatório: Evidências Empíricas no Período de 1998-2013. Tese de Doutorado em Administração, Centro de Pós-Graduação e Pesquisas em Administração - CEPEAD, Universidade Federal de Minas Gerais. Belo Horizonte, MG, Brasil.

McWilliams, A., \& Siegel, D. (2001). Corporate social responsibility: A theory of the firm perspective. Academy of management review, 26(1), 117-127.

Moura, E. A., Dias, A. C., Machado, A. C. S. C., \& Santos, A. T. R. (2017). Estudo de caso da situação econômico-financeira da empresa Arezzo indústria e comércio SA. Revista de Trabalhos Acadêmicos-Universo, 2(3).

Moura, G. D., Theiss, V., \& Cunha, P. R. (2014). Ativos intangíveis e gerenciamento de resultados: uma análise em empresas brasileiras listadas na BM\&FBovespa. BASE-Revista de Administração e Contabilidade da Unisinos, 11(2), 111-122.

Muñoz, R. M., Pablo, J. D. S. D., Salinero, Y., \& Peña, I. (2020). Risk measures and the riskreturn paradox: an analysis in the context of the economic crisis. Revista Brasileira de Gestão de Negócios, 22, 348-362.

Nossa, V., Cezar, J. F., Silva Junior, A., Baptista, É. C. S., \& Nossa, S. N. (2009). A relação entre o retorno anormal e a responsabilidade social e ambiental: um estudo empírico na bovespa no período de 1999 a 2006. BBR-Brazilian Business Review, 6(2), 121-136.

Palmrose, Z. V., Richardson, V. J., \& Scholz, S. (2004). Determinants of market reactions to restatement announcements. Journal of accounting and economics, 37(1), 59-89. 
Prudêncio, P. A., Forte, H. C., De Luca, M. M. M., \& Vasconcelos, A. C. (2019). Disclosure ambiental negativo e desempenho em empresas listadas na B3. Revista de Gestão Social e Ambiental, 13(2), 58-74.

Rao, K., \& Tilt, C. (2016). Board composition and corporate social responsibility: The role of diversity, gender, strategy and decision making. Journal of Business Ethics, 138(2), 327-347.

Rezende, D. A. Sistema de informações organizacionais: guia prático para projetos em cursos de administração, contabilidade e informática. (4a ed.). São Paulo, 2010.

Ribeiro, F., Alves, T. A., Taffarel, M., \& Menon, G. (2017). Responsabilidade social corporativa e o desempenho financeiro no setor de energia elétrica: um estudo com modelo de dados em painéis. Gestão \& Regionalidade, 33(99), 39-54.

Scholtens, B., \& Kang, F. C. (2013). Corporate social responsibility and earnings management: Evidence from Asian economies. Corporate Social Responsibility and Environmental Management, 20(2), 95-112.

Schuster, H. A., \& Klann, R. C. (2019). Responsabilidade Social Corporativa e Gerenciamento de Resultados por Accruals. Contabilidade Vista \& Revista, 30(1), 01-26.

Servaes, H., \& Tamayo, A. (2013). The impact of corporate social responsibility on firm value: The role of customer awareness. Management science, 59(5), 1045-1061.

Shahzad, F., Fareed, Z., Wang, Z., \& Shah, S. G. M. (2020). Do idiosyncratic risk, market risk, and total risk matter during different firm life cycle stages? Physica A: Statistical Mechanics and its Applications, 537, 122-550.

Silva, G. C., Takamatsu, R. T., \& Avelino, B. C. (2017). Adesão aos Níveis Diferenciados de Governança Corporativa e Qualidade das Informações Contábeis. ConTexto, 17(35), 89-104.

Silva, J. P. D., Noriller, R. M., Silva, C. A. T., \& Niyama, J. K. (2018). Earning quality e o desempenho das companhias brasileiras de capital aberto. Revista Ibero-Americana de Estratégia, 17(2), 108-124.

Soares, C. R., Motoki, F. Y. S., \& Monte-Mor, D. S. (2018). IFRS e probabilidade de republicação: Um estudo das empresas brasileiras listadas na Bovespa. Revista Catarinense da Ciência Contábil, 17(52).

Sousa, M. A. B., Fernandes, C. F., Bezerra, R. P. P., \& Ribeiro, S. P. (2016). Qualidade da informação contábil: uma análise de suas características com base na percepção do usuário externo. Iberoamerican Journal of Industrial Engineering, 8(15), 208-227.

Spence, M. (1978). Job market signaling. In Uncertainty in economics (pp. 281-306). Academic Press, 2081-306.

Tavares, H. L. M. (2016). O endividamento e a qualidade da informação financeira (Master's thesis). Dissertação de Mestrado, Universidade Lusófona de Humanas e Tecnologias. 
Wooldridge, J. M. (2007). Inverse probability weighted estimation for general missing data problems. Journal of econometrics, 141(2), 1281-1301.

Ximenes, F. K. A. A., \& Ferreira, F. R. (2021). O efeito das práticas ambientalmente responsáveis sobre a agressividade fiscal: Uma análise das empresas participantes do Índice Carbono Eficiente-ICO2. Pensar Contábil, 22(79), 60-69.

Yasser, Q. R., Al Mamun, A., \& Ahmed, I. (2017). Corporate social responsibility and gender diversity: Insights from Asia Pacific. Corporate Social Responsibility and Environmental Management, 24(3), 210-221.

Zhang, H., Huang, H. J., \& Habib, A. (2018). The effect of tournament incentives on financial restatements: Evidence from China. The International Journal of Accounting, 53(2), 118-135.

\section{ACKNOWLEDGMENTS}

The authors thank the ESTÁCIO FIC Programa Pesquisa Produtividade (Research Productivity Program). 